\title{
A new large didelphid of the genus Thylophorops (Mammalia: Didelphimorphia: Didelphidae), from the late Tertiary of the Pampean Region (Argentina)
}

\author{
FRANCISCO J. GOIN ${ }^{1,2}$, NATALIA ZIMICZ ${ }^{1,2}$, MARTÍN DE LOS REYES ${ }^{3} \&$ LEOPOLDO SOIBELZON $^{1,2}$ \\ ${ }^{1}$ CONICET, Argentina. \\ ${ }^{2}$ División Paleontología Vertebrados, Museo de La Plata, Paseo del Bosque s/n, (B1900FWA) La Plata, Argentina. \\ E-mail:fgoin@fcnym.unlp.edu.ar (F.Goin),nzimicz@fcnym.unlp.edu.ar (N. Zimicz), lsoibelzon@fcnym.unlp.edu.ar (L.Soibelzon). \\ ${ }^{3}$ Undergraduate student, Facultad de Ciencias Naturales y Museo, Universidad Nacional de La Plata, Argentina. \\ E-mail: delosreyess@yahoo.com.ar
}

\begin{abstract}
We describe Thylophorops lorenzinii sp. nov. (Marsupialia, Didelphidae), the largest known didelphid opossum, living or extinct. Its type specimen comes from Late Pliocene levels at Punta San Andrés, southeastern Buenos Aires Province, Argentina. With an estimated body mass between 4.8 and $7.4 \mathrm{~kg}$, it obviously surpasses that of the (up to now) largest didelphid, the living Didelphis virginiana Kerr. In addition to its larger size, the new species differs from T. chapalmalensis Ameghino and T. perplanus Ameghino in that its lower molars have more labially salient hypoconids and proportionally large hypoconulids which are not antero-posteriorly compressed.
\end{abstract}

Key words: Thylophorops lorenzinii sp. nov., Didelphidae, Marplatan Stage/Age, Argentina

\section{Resumen}

Se describe a Thylophorops lorenzinii sp. nov. (Marsupialia: Didelphidae), la zarigüeya más grande, fósil o viviente, hasta ahora conocida. Su ejemplar tipo procede de niveles del Plioceno Tardío de Punta San Andrés, en el sudeste de la Provincia de Buenos Aires, Argentina. Con una masa corporal estimada entre 4,7 y 7,5 kg, sobrepasa claramente aquella del (hasta ahora) más grande didélfido conocido, Didelphis virginiana Kerr. Más allá de su mayor tamaño, la nueva especie difiere de $T$. chapalmalensis Ameghino y T. perplanus Ameghino en que sus molares inferiores tienen hipoconúlidos proporcionamente grandes, los cuales no están comprimidos anteroposteriormente, y en que los hipocónidos son más salientes labialmente.

Palabras clave: Thylophorops lorenzinii sp. nov., Didelphidae, Piso/Edad Marplatense, Argentina.

\section{Introduction}

Large sized, 2n=22 opossums (Marsupialia: Didelphidae: Didelphinae; Reig et al. 1977, Kirsch \& Palma 1995) are widely distributed throughout the Americas, especially in tropical South America. However, their late Cenozoic history and taxonomy is mostly known from fossil sites in higher latitudes such as those of the Pliocene-Pleistocene deposits in the Pampean Region (Goin 1995). A remarkable aspect of these late Cenozoic associations is that didelphines show a decided trend toward more carnivorous-faunivorous feeding habits, as revealed by their dental specializations. One example of this trend is the extinct Thylophorops Ameghino, a genus showing affinities with Didelphis Linnaeus and Philander Brisson (Goin 1991, contra 
Simpson 1972). Thylophorops is mostly known for its type species, the Late Pliocene (Chapadmalalan Stage/ Age) T. chapalmalensis Ameghino. A second, smaller species from the Early Pliocene of the Pampean Region, T. perplanus Ameghino, was more recently recognized by Goin \& Pardiñas (1996; mentioned there as "T. aff. perplana"). Here we describe a new, Late Pliocene (Marplatan Stage/Age) species of Thylophorops, which represents the largest didelphid opossum known to date, as well as the last (youngest) species of this genus. We comment on its main features, inferred body mass and probable feeding habits.

\section{Material, methods, provenience, and abbreviations}

The type specimen of the new species (Figs. 1-4) belongs to the MLP collections (División Paleontología Vertebrados, Museo de La Plata, Argentina). Specimen of T. chapalmalensis MPH 064 in Fig. 4 (left, detail of m3) and Fig. 5 (D-E) belongs to the Museo de Punta Hermengo (Miramar) collections, while specimen of this same species illustrated in Fig. 5 (A-C) is MLP 64-XI-12-1. The figured specimen of T. perplanus (Figs. 4 right and 6) is MLP 97-XI-15-1. Body mass (Table 1) was calculated following procedures detailed in Gordon (2003). Feeding habits were inferred from analyses of molar crests and, in worn specimens of other species of the genus, wear facets as detailed in Dewar (2003). The type specimen comes from Punta San Andrés (38 $10^{\circ}$ 52.92" S-57 39' 11.66" W; see Verzi \& Quintana 2005: fig. 3), General Pueyrredón County, Buenos Aires Province, Argentina. Mammal-bearing deposits at this site belong to Level 2, San Andrés Formation, Sanandresan Stage/Age (latest Pliocene; see Verzi \& Quintana 2005: figs. 2, 3). The specimen was extracted from a medium-sized paleocave $(110 \mathrm{~cm}$ in diameter), most probably generated by a fossorial, extinct xenarthran. Details on the geology, stratigraphy, sedimentology, chronology, and faunal context of this locality were given by Verzi \& Quintana (2005 and literature cited therein). Abbreviations: Ma, Mega-annum; c, p, m, lower canine, premolar and molar, respectively; dp3, deciduous premolar. Molar nomenclature follows Goin et al. (2003). L, length; W, width. Measurements are in mm.

TABLE 1: Body mass estimations in selected large didelphids, extant and extinct. BM, body mass; L, length; A, area; g, grams; $\mathrm{r}^{2}$, Determination Index; $\mathrm{LM}_{\mathrm{x}}$, Molar length; $\mathrm{AM}_{\mathrm{x}}$, Molar Area; $\mathrm{N}$, sample size.

\begin{tabular}{|c|c|c|c|c|c|}
\hline Taxa & Equation & $r^{2}$ & $\mathrm{LM}_{\mathrm{x}}(\mathrm{mm})$ & $\mathrm{AM}_{\mathrm{x}}\left(\mathrm{mm}^{2}\right)$ & Body Mass (g) \\
\hline Didelphis marsupialis & Data from Gordon (2003) & & & & $\begin{array}{l}1,265.2 \text { (males) } \\
1,400 \text { (females) }\end{array}$ \\
\hline Didelphis virginiana & Data from Gardner (1982) & & & & $\begin{array}{l}\text { 2,970 (males) } \\
2,070 \text { (females) }\end{array}$ \\
\hline Didelphis albiventris & $\begin{array}{l}\operatorname{Ln}(B M)=1.59+3.228 \times \ln (m 3 L) \\
\operatorname{Ln}(B M)=2.363+1.635 \times \ln (m 3 A)\end{array}$ & $\begin{array}{l}0.970 \\
0.964\end{array}$ & $\mathrm{~m}_{3}=5.39$ & $\mathrm{~m}_{3}=15.35$ & $\begin{array}{l}1,442.72 \\
1,057.30\end{array}$ \\
\hline Lutreolina crassicaudata & $\begin{array}{l}\operatorname{Ln}(B M)=1.59+3.228 \times \ln (m 3 L) \\
\operatorname{Ln}(B M)=2.363+1.635 \times \ln (m 3 A)\end{array}$ & $\begin{array}{l}0.970 \\
0.964\end{array}$ & $\begin{array}{l}\mathrm{m}_{3}=3.68 \\
\mathrm{~N}=10\end{array}$ & $\begin{array}{l}\mathrm{m}_{3}=8.21 \\
\mathrm{~N}=10\end{array}$ & $\begin{array}{l}397.87 \\
371.96\end{array}$ \\
\hline Hyperdidelphys inexpectata & $\begin{array}{l}\operatorname{Ln}(B M)=1.59+3.228 \times \ln (m 3 L) \\
\operatorname{Ln}(B M)=2.363+1.635 \times \ln (m 3 A)\end{array}$ & $\begin{array}{l}0.970 \\
0.964\end{array}$ & $\begin{array}{l}\mathrm{m}_{3}=5.18 \\
\mathrm{~N}=1\end{array}$ & $\begin{array}{l}\mathrm{m}_{3}=14.89 \\
\mathrm{~N}=1\end{array}$ & $\begin{array}{l}994.18 \\
879.21\end{array}$ \\
\hline Hyperdidelphys parvula & $\begin{array}{l}\operatorname{Ln}(B M)=1.59+3.228 \times \ln (m 3 L) \\
\operatorname{Ln}(B M)=2.363+1.635 \times \ln (m 3 A)\end{array}$ & $\begin{array}{l}0.970 \\
0.964\end{array}$ & $\begin{array}{l}\mathrm{m}_{3}=5.17 \\
\mathrm{~N}=1\end{array}$ & $\begin{array}{l}\mathrm{m}_{3}=15.72 \\
\mathrm{~N}=1\end{array}$ & $\begin{array}{l}984.93 \\
960.26\end{array}$ \\
\hline Thylophorops perplanus & $\begin{array}{l}\operatorname{Ln}(B M)=1.59+3.374 \times \ln (m 2 L) \\
\operatorname{Ln}(B M)=2.403+1.67 \times \ln (m 2 A)\end{array}$ & $\begin{array}{l}0.968 \\
0.968\end{array}$ & $\begin{array}{l}\mathrm{m}_{2}=5.47 \\
\mathrm{~N}=1\end{array}$ & $\begin{array}{l}\mathrm{m}_{2}=15.75 \\
\mathrm{~N}=1\end{array}$ & $\begin{array}{l}1,515.30 \\
1,104.67\end{array}$ \\
\hline Thylophorops chapalmalensis & $\begin{array}{l}\operatorname{Ln}(B M)=1.59+3.228 \times \ln (m 3 L) \\
\operatorname{Ln}(B M)=2.363+1.635 \times \ln (m 3 A)\end{array}$ & $\begin{array}{l}0.970 \\
0.964\end{array}$ & $\begin{array}{l}\mathrm{m}_{3}=7.59 \\
\mathrm{~N}=6\end{array}$ & $\begin{array}{l}\mathrm{m}_{3}=32.11 \\
\mathrm{~N}=6\end{array}$ & $\begin{array}{l}3,406.09 \\
3,087.85\end{array}$ \\
\hline Thylophorops lorenzinii sp. nov. & $\begin{array}{l}\operatorname{Ln}(B M)=1.59+3.228 \times \ln (m 3 L) \\
\operatorname{Ln}(B M)=2.363+1.635 \times \ln (m 3 A)\end{array}$ & $\begin{array}{l}0.970 \\
0.964\end{array}$ & $\begin{array}{l}\mathrm{m}_{3}=9.69 \\
\mathrm{~N}=1\end{array}$ & $\begin{array}{l}\mathrm{m}_{3}=42.44 \\
\mathrm{~N}=1\end{array}$ & $\begin{array}{l}7,488.26 \\
4,871.77\end{array}$ \\
\hline
\end{tabular}




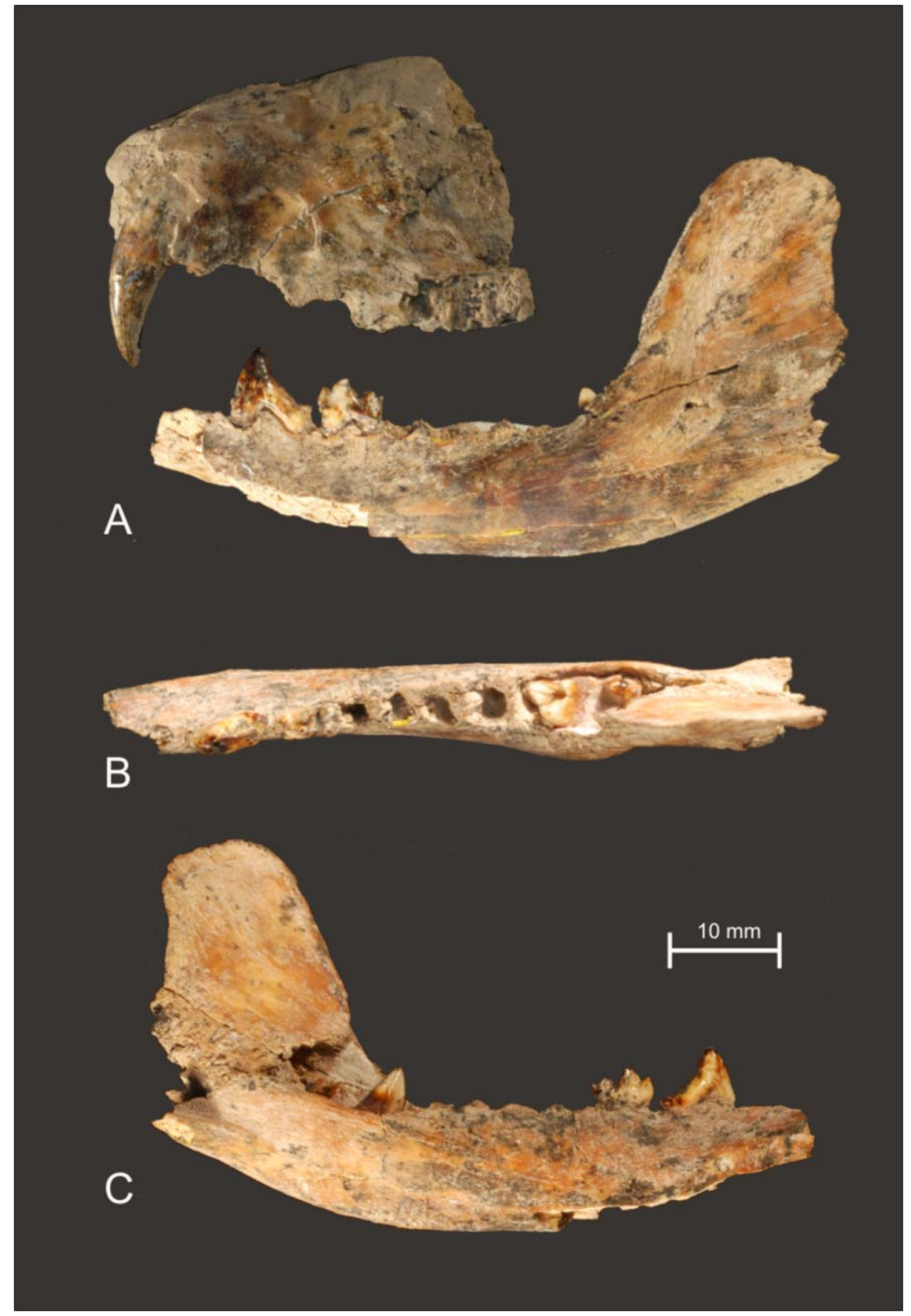

FIGURE 1: Thylophorops lorenzinii sp. nov. MLP 08-III-10-1 (Holotype); (A), labial view of the anterior part of the skull and dentary; (B) occlusal view of the dentary; (C) lingual view of the dentary. Scale: $10 \mathrm{~mm}$. 


\section{Systematic paleontology}

\section{Thylophorops lorenzinii, new species}

Figs. 1-4

Holotype. MLP 08-III-10-1, a fragment of skull preserving the left maxilla, and a left dentary preserving the second premolar (p2), the deciduous premolar (dp3) and an erupting third molar (m3), all belonging to the same, juvenile specimen. Collected by Leopoldo Soibelzon in January, 2008.

Etymology. Honouring Mr. Silvio Lorenzini, outstanding amateur collector of fossil specimens in Southeastern Buenos Aires Province.

Measurements. Extra-alveolar length of upper canine (C): 10.15; CL: 4.33; CW: 3.41; height of dentary at $\mathrm{m} 3$ : 11.87; width of dentary at same point: 8.08 ; length of the p2-m3 series: $40.02 \mathrm{~mm}$; p2L: 7.64; p2W: 3.22; dp3L: 5.76; dp3W: 2.83; m3L (total): 9.69; trigonid m3L: 4.22; talonid m3L: 5.47; talonid m3W: 4.31; trigonid m3W: 4.38 (see also Fig. 3).

Diagnosis. Largest known didelphid; differs from the other species of Thylophorops in having its lower molars with proportionally large hypoconulids which are not antero-posteriorly compressed; labially salient hypoconids; $\mathrm{p} 2$ is proportionally larger, higher, and posteriorly wider than in T. chapalmalensis and T. perplanus.

Description of the holotype. Specimen MLP 08-III-10-1 belongs to a juvenile individual, as evidenced by the persistence of a dp3 and an erupting $\mathrm{m} 3$ which is placed immediately anterior to the masseteric crest (i.e. $\mathrm{m} 4$ is not observable). Only the anterior part of the snout is preserved (Fig. 1A), which is broken. The dentary (Fig. 1B-C) is partially broken and lacks the incisor region and the angular process; it is quite robust, especially under $\mathrm{m} 3$. The posterior end of the symphysis reaches the distal margin of $\mathrm{p} 2$. The mental foramen is in line with the mesial root of $\mathrm{m} 1$. The distal root of $\mathrm{p} 1$, and complete $\mathrm{p} 2, \mathrm{dp} 3$ and $\mathrm{m} 3$ are preserved.

The $\mathrm{p} 2$ is large and high. The crown is relatively narrow over the mesial root but is much wider and more robust over the distal root. The posterior cingulum ends near the labial side of the talonid.

The dp3 is the smallest tooth of this specimen; the trigonid and talonid are similar in length, but the talonid is wider. The metaconid is slightly smaller than the protoconid and is located on the posterolabial margin of the trigonid. The small paraconid is positioned anteromedially. The entoconid is the highest cusp of the talonid; the hypoconid is labially salient.

The erupting $\mathrm{m} 3$ (Fig. 2) is very large, with its trigonid slightly longer than the talonid. All cusps are well preserved. The paraconid is triangular in occlusal view; its postero-lingual side is flat. In contrast, in $T$. chapalmalensis (Fig. 4, left), this side is rounded and the cusp is conical in occlusal view. The protoconid is the highest and largest cusp of the trigonid; it lies on the lingual side and occupies almost the entire trigonid surface. The metaconid is proportionally larger than that of $T$. chapalmalensis. The talonid is well developed in all dimensions. The entoconid is tall and prominent. The hypoconulid is large and well developed anteroposteriorly. The entoconid and hypoconulid are similar in size, in sharp contrast with T. capalmalensis, in which the entoconid is much larger. The hypoconid is located on the labial side of the talonid and is noticeably salient.

\section{Body mass and inferred feeding habits}

The use of dental measurements to estimate the body mass has been widely analized for many authors mainly due to the predominance of this elements in the mammalian fossil record (see Gingerich et al., 1982; Gingerich and Smith, 1984; Legendre and Roth, 1988; Janis, 1990; Damuth, 1990; Fortelius, 1990). Molar magnitudes are highly correlated with body mass, particularly the antero-posterior length and area, which show high values of determination index $\left(r^{2}\right)$ in the regression analysis; the election of one or another measurement is 
mainly based on this index. Some authors suggest that length is more reliable because the area is a composite variable that also includes the molar width, and this last one is subject to adaptative variation; on the contrary, length is more constant among the various species (Fortelius, 1990; Damuth, 1990). In the case of marsupials, Gordon (2003) analyzed the the relation of molar measurements to body mass in dental conservative species. She extended the analysis to all molar loci and concluded that there is a high correlation between weight and/ or lengh and molar area in all loci, with the highest values of $\mathrm{r}^{2}$ for the first upper and lower molars. Anyway, the posterior molars are also good predictors, as their determination index is always above 0.9.

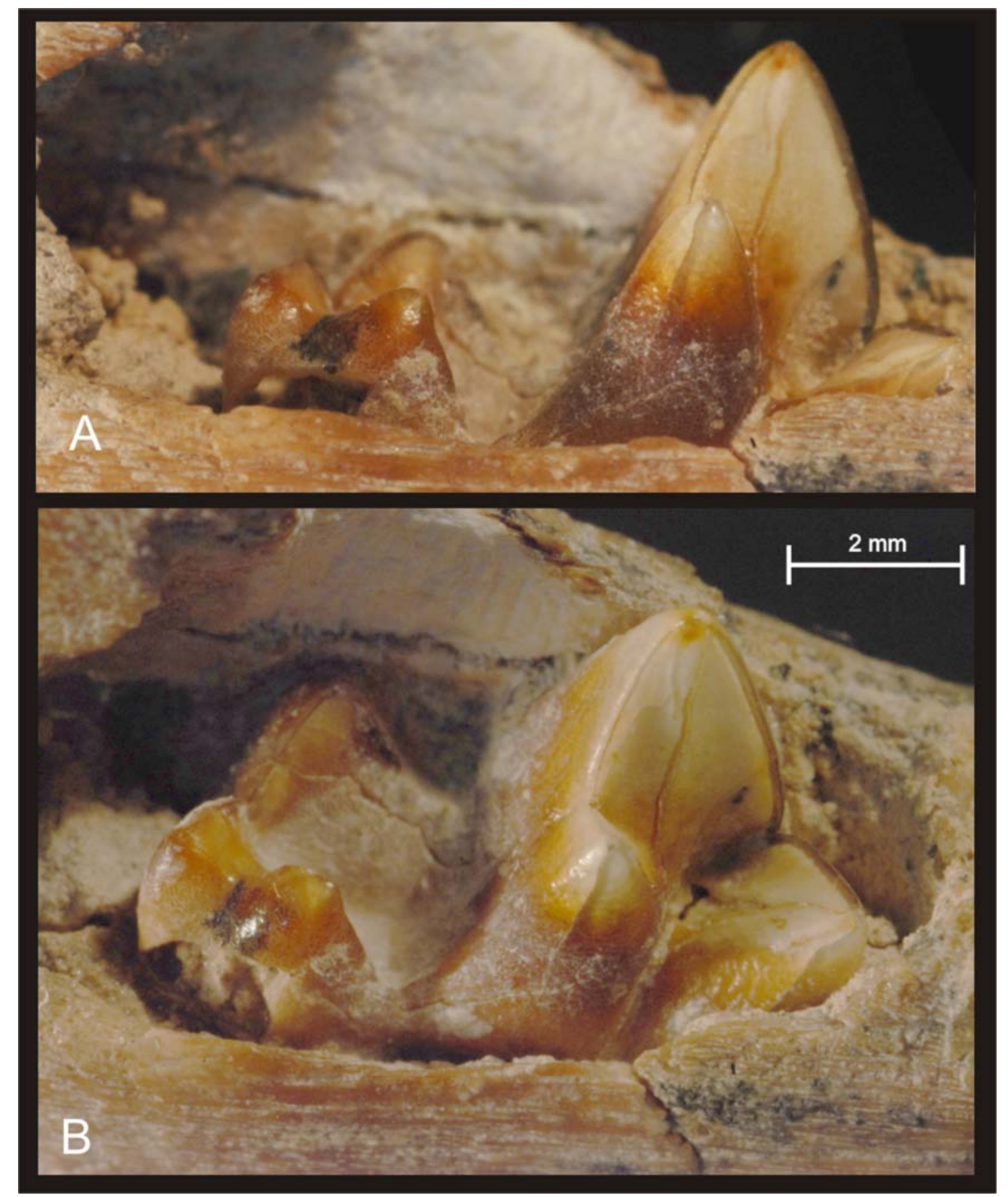

FIGURE 2: Thylophorops lorenzinii sp. nov. MLP 08-III-10-1 (Holotype); detail of the erupting m3 in lingual (A), and occlusal-lingual views (B). Scale: $2 \mathrm{~mm}$.

In the estimation of the body mass of $T$. lorenzinii, we have followed Gordon's sample including didelphids (except Caluromys) and dasyurids. The exclusion of Caluromys results from its peculiar dentition, wich 
shows a sharp decline in molar size in m3-4 as compared to m2. Because of this, Caluromys is an outlier and, as such, significantly alters the correlation index (Gordon, 2003). All other didelphids, including T. lorenzinii, are more dentally conservative in showing a size progression from $\mathrm{m} 1$ to $\mathrm{m} 3$. In short, the exclusion of Caluromys from the sample increase the predictive potential of the equations. Finally, the equations are derived from a pooled sample (didelphid + dasyurid) because the resulting range in the values of the independent variable is wider than that obtained from the single didelphid sample. As T. lorenzinii exceeds in molar size that of all other living or extinct didelphid, the former would be out of range in the didelphid regression.

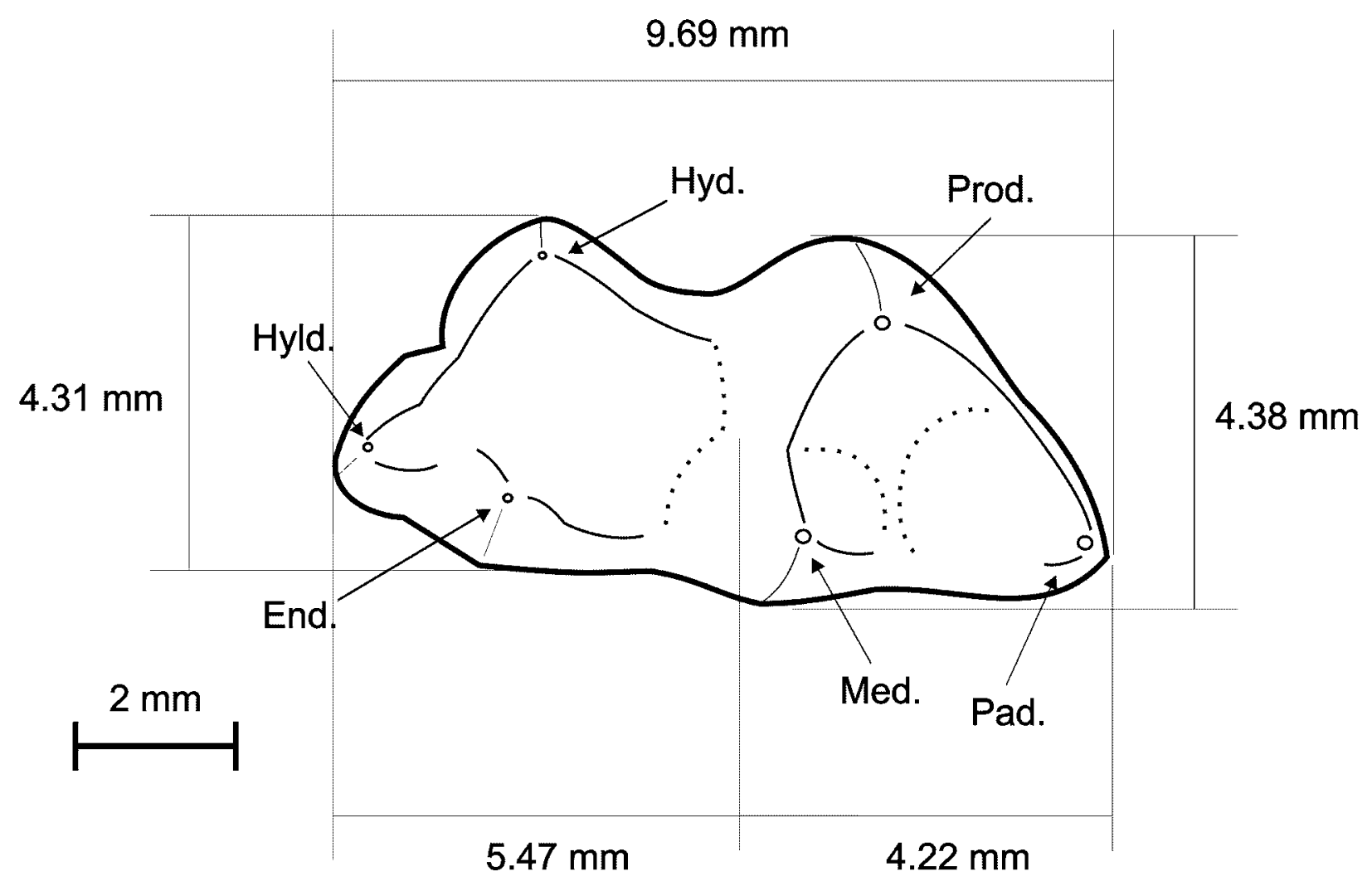

FIGURE 3: Thylophorops lorenzinii sp. nov. MLP 08-III-10-1 (Holotype); schematic drawing of the m3 showing the cusp homologies and measurements. Abbreviations: End., entoconid; Hyd., hypoconid; Hyld., hypoconulid; Med., metaconid; Pad., paraconid; Prod., protoconid. Scale: $2 \mathrm{~mm}$.

For comparative purposes we extended our calculations to the remaining species of Thylophorops: T. chapalmalensis (Fig. 5) and T. perplanus (Fig. 6), as well as to two species of Hyperdidelphys, another large, extinct didelphid. The molar locus used is the $\mathrm{m} 3$ with the exception of $T$. perplanus, in which the analyzed molar values are those of the $\mathrm{m} 2$. Table 1 summarizes the equations, associated coefficients, and estimated body masses for selected large didelphids. Estimations were obtained both from molar length and molar area. Because of the lack of published data on measurements of individual molars for D. virginiana, the largest living opossum, this species was not added to the pooled sample. Weight measurements for this species in Table 1 were taken from Gardner (1982).

Even though the regression coefficients are similar for all estimations, in $T$. lorenzinii we note significant differences between the calculated weight from $\mathrm{m} 3$ length and that of $\mathrm{m} 3$ area. This is not the case of other results based on the same equations for other large didelphid species, living or extinct (see Table 1). This can be due to the high sensitivity of the least square regression to extreme values on the independent variable. For didelphids + dasyurids, the logarithmic range in the $\mathrm{m} 3$ length equation fluctuates from 0.3 to 2.4 , while for the $\mathrm{m} 3$ area it does from 0.2 to 4.4 (Gordon, 2003). The logarithmic values for T. lorenzinii are 2.2 for the $\mathrm{m} 3$ 
length and 3.7 for the $\mathrm{m} 3$ area. Both values fall within the extremes of the regression line (Fig. 7), but the $\mathrm{m} 3$ area is closer to the mean value of its respective regression. As the predictive potential for marginal values of the independent variable is lower than that of the central ones, we understand that the most realistic estimation of the body mass of $T$. lorenzinii is that one obtained from the $\mathrm{m} 3$ area.

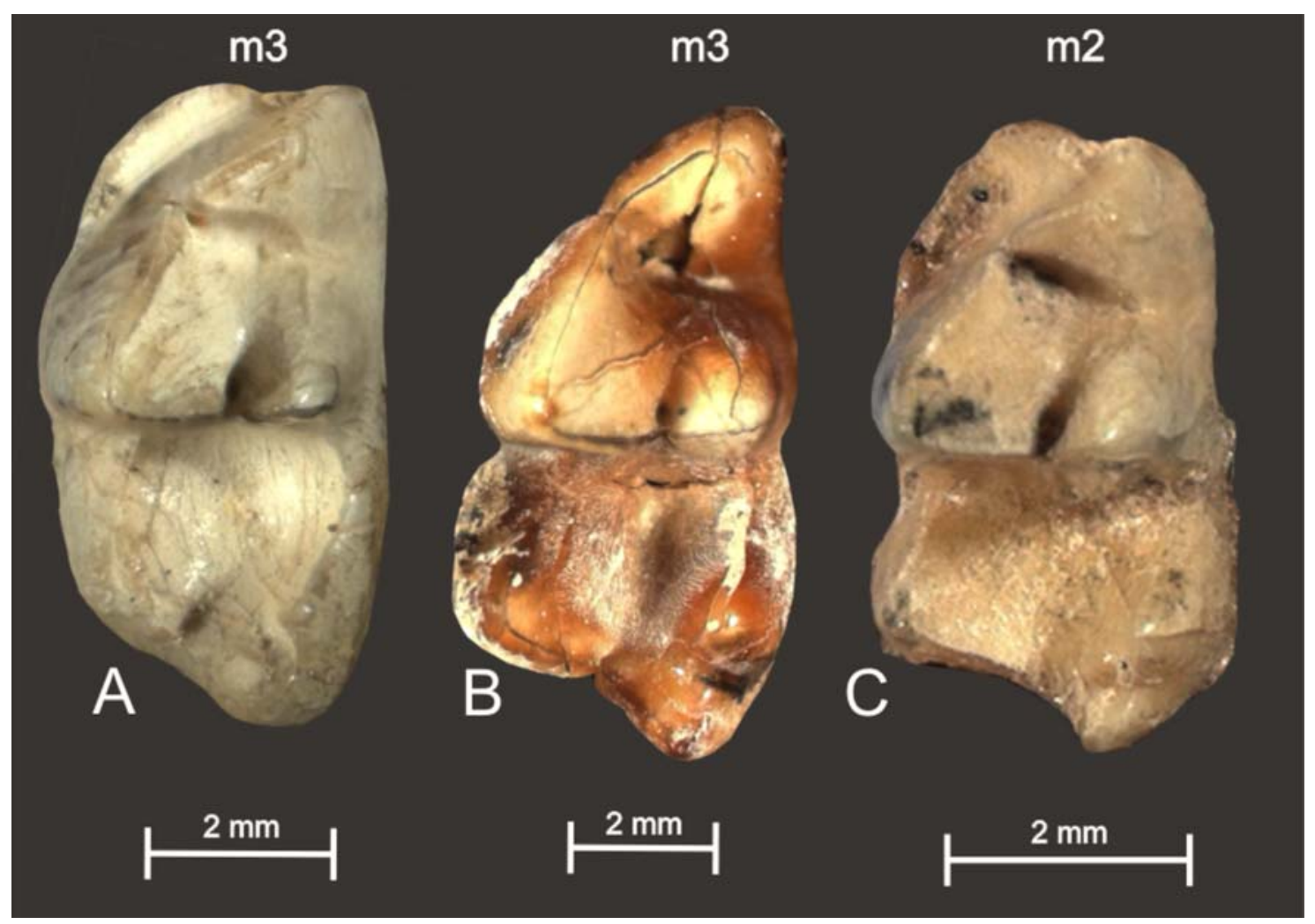

FIGURE 4: Lower left molars of Thylophorops chapalmalensis (left, detail of specimen MPH 064), T. lorenzinii sp. nov. (centre, detail of the type specimen), and T. perplanus (right, detail of specimen MLP 97-XI-15-1). Because of the erupting stage of the $\mathrm{m} 3$ of $T$. lorenzinii in the type specimen, the anterobasal cingulum is not visible. Scale: $2 \mathrm{~mm}$.

In order to test the ability of Gordon's (2003) equations for the prediction of body mass, we measured the m3 length and area of ten MLP specimens belonging to Lutreolina crassicaudata (a species not included in Gordon's sample) and Didelphis albiventris. Results are shown in Table I. Known weight of L. crassicaudata ranges from 200 and $540 \mathrm{~g}$ (Grzimek et al., 2003) and that of D. albiventris is between 1265.2 (males) and 1400 (females; Gordon, 2003). It can be seen that both equations predict equally well the body size of these two species, which, in the didelphid + dasyurid sample, are close to the mean values in molar size. This reinforces the idea that the high body mass value obtained for $T$. lorenzinii from $\mathrm{m} 3$ length is due to its marginal position within the sample range.

The largest living didelphid is Didephis virginiana, whose body mass published estimations vary between 0.8-6.4 kg for males, and 0.3-3.7 kg for females (Wilson \& Ruff 1999). Notwithstanding, it is unclear whether or not some of these weights are based on captive animals. McNab (1978) averaged in $3.7 \mathrm{~kg}$ the body mass of this species. Earlier, McManus (1974) mentioned an average body mass of $2.8 \mathrm{~kg}$ for males and $1.9 \mathrm{~kg}$ for females of this same species. By far, the most complete published measurements of body mass for D. virginiana are those of Gardner (1982), in which he gave average weights for 374 males and 296 females from North America, all of them sorted by region. Averaging the numbers given for each lot, mean values for body weight are $2.97 \mathrm{~kg}$ for males, and 2.07 for females, with an average body weight of $2.52 \mathrm{~kg}$. With an estimated mean body mass of $4.8 \mathrm{~kg}$, T. lorenzinii almost doubles that of the largest living didelphid. In conclusion, $T$. lorenzinii is the largest known didelphid, living or extinct. 


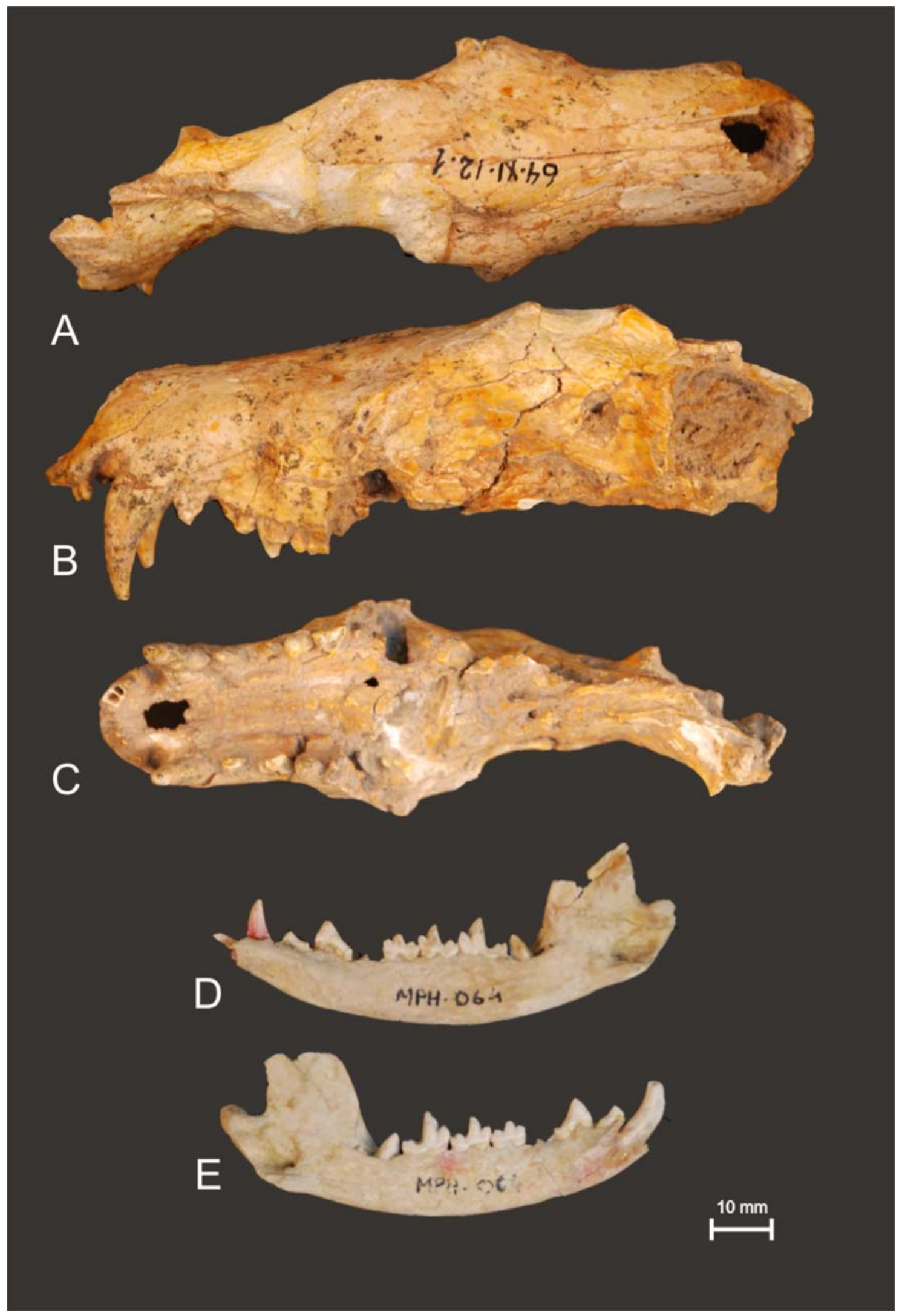

FIGURE 5: Thylophorops chapalmalensis Ameghino. A-C, detail of the rostrum and medial portion of the skull of an adult individual (MLP 64-XI-12-1) in dorsal (A), lateral (B), and ventral (C) views; D-E, detail of both mandibles of a juvenal specimen (MPH 064; D, right mandible in lingual view; E, left mandible in lingual view). In both mandibles, the erupting molar is $\mathrm{m} 4$. Scale: $10 \mathrm{~mm}$. 


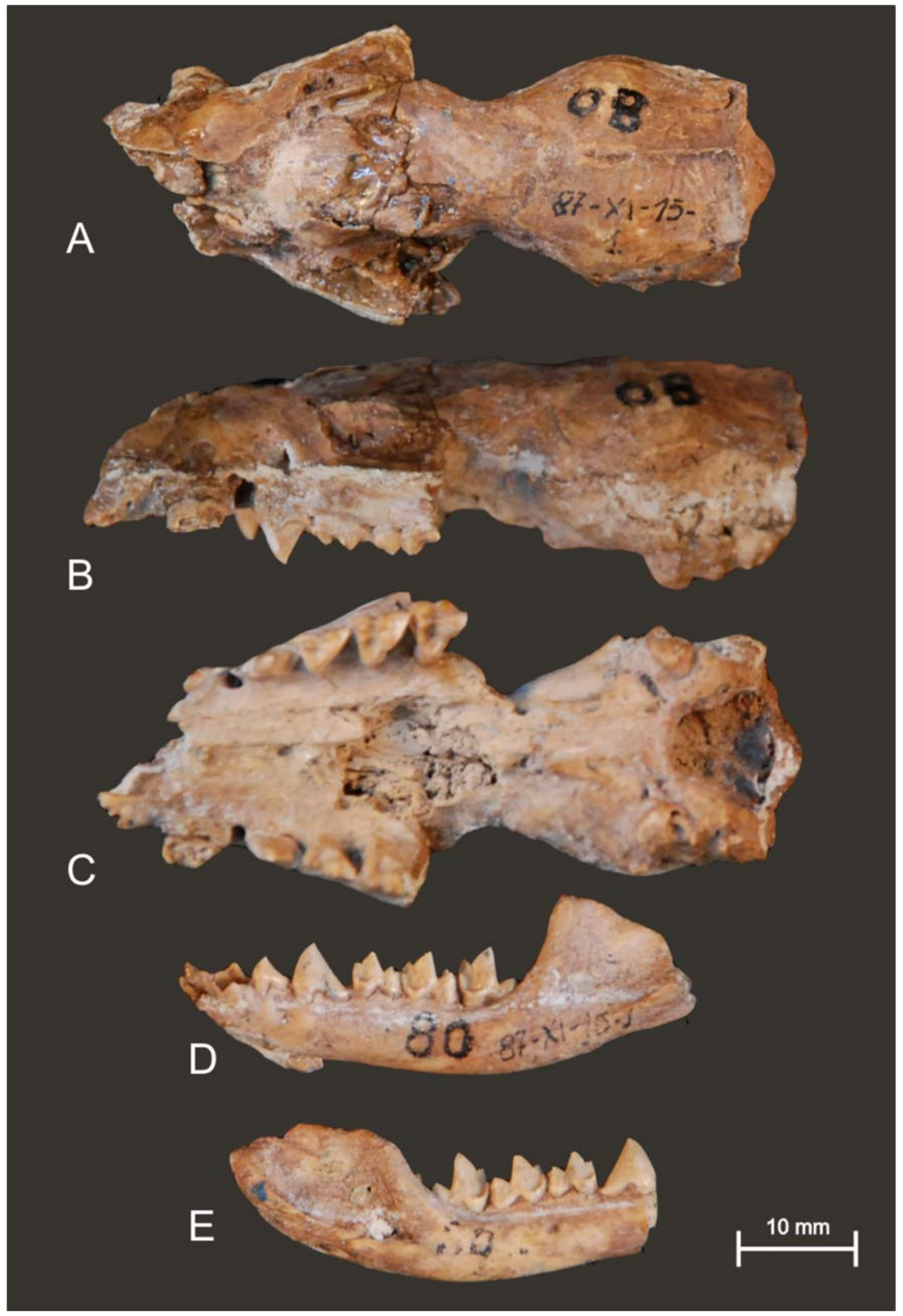

FIGURE 6: Thylophorops perplanus (Ameghino). MLP 87-XI-15-1, a juvenile specimen preserving a partial skull (A, dorsal; B, lateral, and C, ventral views) and fragments of both mandibles (D, left mandible in labial view; E, right mandible in labial view). Scale: $10 \mathrm{~mm}$. 


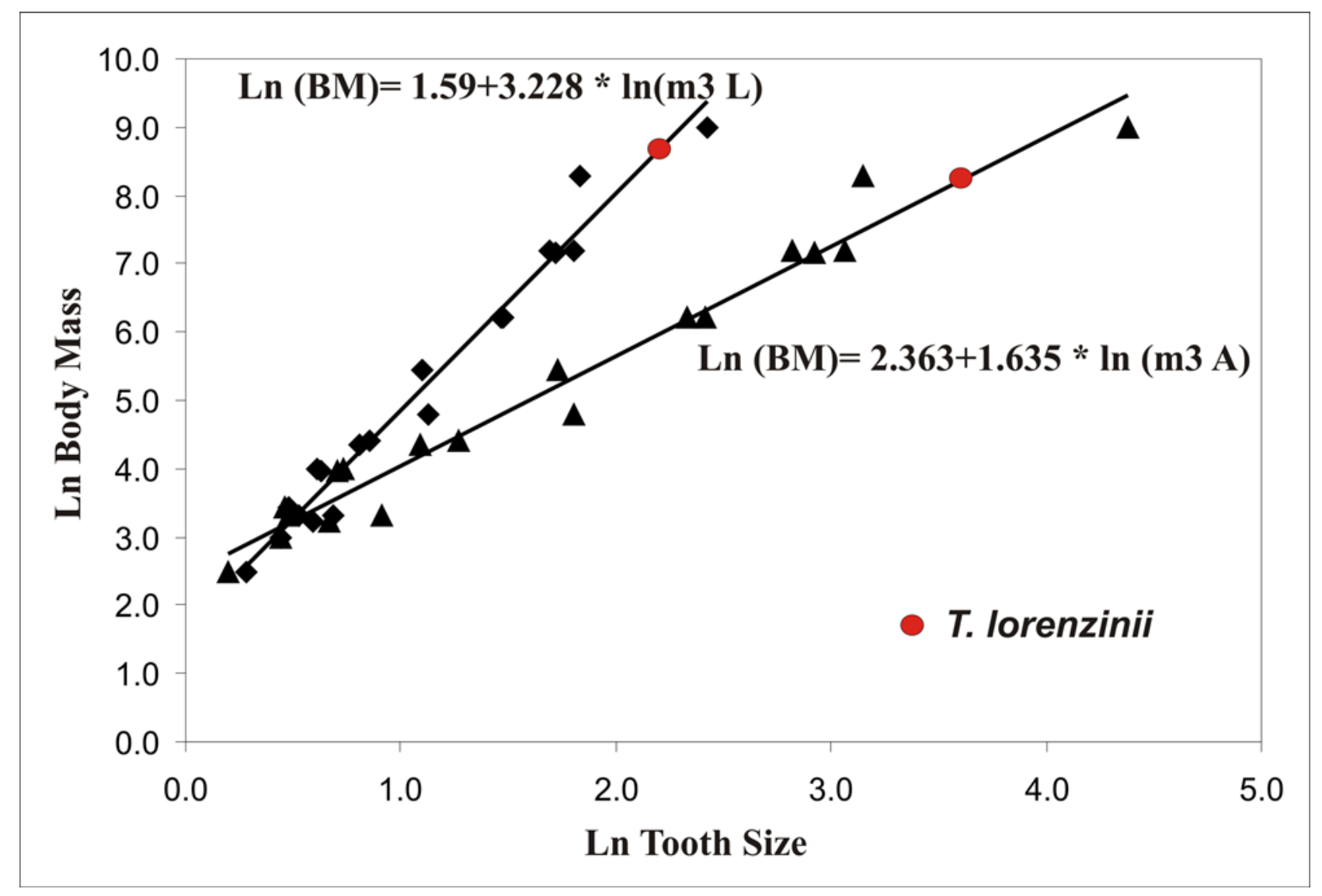

FIGURE 7: Regression plots showing the relationships between mean body mass and molar size (length and area). The red circle indicates the position of T. lorenzinii. See Table 1 for abbreviations.

Feeding habits of T. lorenzinii are inferred mainly by comparison with other species of the genus Thylophorops. The wear facet pattern observed in T. chapalmalensis (Zimicz, pers. obs.) is consistent with an omnivorous diet trending to carnivory, as the most developed wear facets in this species correspond to those of shearing activity (79.1\% of the total wear facets). Although grinding surfaces (talonid, protocone) are developed in all three species of Thyophorops, they were less omnivorous than Didelphis albiventris, as indicated by an even larger development of grinding facets in the latter.

\section{Remarks}

The new species T. lorenzinii is clearly referable to the genus Thylophorops on the basis of the following aspects: (1) its large size; (2) it lacks the somewhat bunoid cusps and less trenchant crests typical of the species of Didelphis, and (3) its talonid basin is proportionally larger than that of the species of Hyperdidelphys. On the other side, it shares most of the molar features that characterize other known species of Thylophorops (see Goin \& Pardiñas, 1996).

Specimen MLP 08-III-10-1 is the only specimen so far known that can be unequivocally assigned to Thylophorops lorenzinii. A couple of specimens of T. chapalmalensis have proportionally large size (see Simpson 1972, Goin 1991); however, none of them show the diagnostic features of the holotype of T. lorenzinii in their lower molars or approach its absolute size. T. lorenzinii is only known from the Sanandresan Substage of the Marplatan Stage/Age. Further research should explore its possible function as an index species for the Sanandresan or, alternatively, for the whole Marplatan Stage (Late Pliocene). 
Previous studies of the faunal association recovered from levels of the San Andrés Formation reveal a peculiar assemblage characterized by the large numbers of first records of taxa. Caviomorph rodents have been recently reviewed by Verzi \& Quintana (2005: 303); they concluded that the San Andrés caviomorph assemblage is the "...most clearly indicative of arid environments so far recorded. Its episodic character and composition, and the available palaeomagnetic data, reinforce the hypothesis that it is probably coeval with the profound Late Pliocene cooling and drying pulse detected worldwide around 2.5 Ma." (Verzi \& Quintana 2005: 303). Based on that climatic event, Verzi \& Quintana (2005) inferred that the caviomorph fauna of San Andrés is composed mostly of immigrant taxa from western Argentina, taxa that reached the more eastern Chapadmalalan area during the expansion of arid environments by ca. $2.5 \mathrm{Ma}$. The sudden appearance of $T$. lorenzinii in the fossil record seems to agree with these inferences, although we do not know the source area of this species in South America -either the Monte environments of western Argentina or, alternatively, the less arid, more forested Chaco habitats of northern Argentina and Paraguay.

\section{Acknowledgements}

We thank Bruno Pianzola for the photographs that illustrate this report and Marcela Tomeo for her help with designing the illustrations. Reviewers Analía Forasiepi, Alfred Gardner and Sandrine Ladeveze much helped in improving the original manuscript. L. Soibelzon thanks CONICET and ANPCyT PICT 83171/05 (Argentina) for their financial support during the field work. F. Goin thanks CONICET (Argentina, PIP 5621) and the Alexander von Humboldt Foundation (Germany) for their financial and logistic support.

\section{References}

Damuth, J. (1990) Problems in estimating body masses of archaic ungulates using dental measurements. In: Damuth, J. \& Macfadden, B.J. (Eds), Body Size in Mammalian Paleobiology. Estimation and Biological Implications. Cambridge University Press, Cambridge, pp. 229-253.

Dewar, E.W. (2003) Functional diversity within the Littleton Fauna (early Paleocene) Colorado: evidence from body mass, tooth structure and tooth wear. Paleobios, 23 (1), 1-19.

Fortelius, M. (1990) Problems with using fossil teeth to estimate body size of extinct mammals. In: Damuth, J. \& Macfadden, B.J. (Eds), Body Size in Mammalian Paleobiology. Estimation and Biological Implications. Cambridge University Press, Cambridge, pp. 207-228.

Gardner, A.L. (1982) Virginia opossum. In: Chapman, J.A. \& Feldhamer, G.A. (Eds), Wild Mammals of North America. The John Hopkins University Press, Baltimore, pp. 3-36.

Gingerich, P. D. \& Smith, B. H. (1984) Allometric scaling in the dentition of primates and insectivores. In: W. L. Jungers (Ed), Size and Scaling in Primate Biology. Plenum Press, New York, pp. 257-272.

Gingerich, P. D.; Smith, B. H. \& Rosenberg, K. (1982) Allometric scaling in the dentition of primates and prediction of body weight from tooth size in fossils. American Journal of Physical Anthropology, 58, 81-100.

Goin, F.J. (1991) Los Didelphoidea (Mammalia, Marsupialia, Didelphimorphia) del Cenozoico Tardío de la Región Pampeana. Unpublished thesis, Universidad Nacional de La Plata, 327 pp.

Goin, F.J. (1995) Los Marsupiales. In: Alberdi, M.A., Leone, G. \& Tonni E.P. (Eds), Evolución biológica y climática de la Región Pampeana durante los últimos cinco millones de años. Un ensayo de correlación con el Mediterráneo occidental. Consejo Superior de Investigaciones Científicas, Madrid, pp. 165-179.

Goin, F.J. \& Pardiñas U.F.J. (1996) Revisión de las especies del género Hyperdidelphys Ameghino, 1904 (Mammalia, Marsupialia, Didelphidae). Su significación filogenética, estratigráfica y adaptativa en el Neógeno del Cono Sur Sudamericano. Estudios Geológicos, 52, 327-359.

Goin, F.J., Candela, A. \& Muizon, C. de (2003) The affinities of Roberthoffstetteria nationalgeographica (Marsupialia) and the origin of the polydolopine molar pattern. Journal of Vertebrate Paleontology, 23 (4), 869-876.

Gordon, C.L. (2003) A first look at estimating body size in dentally conservative marsupials. Journal of Mammalian Evolution, 10 (1/2), 1-21.

Grzimek, B., Schlager, N., Olendorf, D. (2003) Grzimek's Animal Life Encyclopedia. Volume 12: Mammals I. Thompson Gale, Farmington Hills, 372 pp. 
Janis, C.M. (1990) Correlation of cranial and dental variables with body size in ungulates and macropodoids. In: Damuth, J. \& Macfadden, B.J. (Eds), Body Size in Mammalian Paleobiology. Estimation and Biological Implications. Cambridge University Press, Cambridge. pp. 255-299.

Kirsch, J.A.W. \& Palma, R.E. (1995) DNA/DNA hybridization studies of carnivorous marsupials. V. A further estimate of relationships among opossums (Marsupialia: Didelphidae). Mammalia, 59, 403-425.

Legendre, S. \& Roth, C. (1988) Correlation of carnassial tooth size and body weight in Recent carnivores (Mammalia). Historical Biology, 1, 85-98.

McNab, B. K. (1978) The comparative energetics of Neotropical marsupials. Journal of Comparative Physiology, 125, $115-128$.

McManus, J.J. (1974) Didelphis virginiana. Mammalian Species, 40, 1-6.

Reig, O.A., Gardner, A.L., Bianchi, N.O. \& Patton, J.L. (1977) The chromosomes of the Didelphidae (Marsupialia) and their evolutionary significance. Biological Journal of the Linnean Society, 9, 191-216.

Simpson, G.G. (1972) Didelphidae from the Chapadmalal Formation in the Museo Municipal de Ciencias Naturales of Mar del Plata. Revista del Museo Municipal de Ciencias Naturales de Mar del Plata, 2, 1-40.

Verzi, D.H. \& Quintana, C.A. (2005) The caviomorph rodents from the San Andrés Formation, east-central Argentina, and global Late Pliocene climatic change. Palaeogeography, Palaeoclimatology, Palaeoecology, 219, 303-320.

Wilson, D. \& Ruff, S. (1999) The Smithsonian Book of North American Mammals. Smithsonian Institution Press, Washington, $750 \mathrm{pp}$. 